\title{
Rozi Souzanzan
}

English Language Instructor, PhD Candidate in TEFL

English Language Department, Shiraz Branch, Islamic Azad University, Shiraz, Iran

r.souzanzan@yahoo.com

\section{Mohammad Sadegh Bagheri}

Assistant professor, PhD in TEFL

English Language Department, Shiraz Branch, Islamic Azad University, Shiraz, Iran

bagheries@gmail.com

\section{IRANIAN LEARNERS' PERCEPTIONS OF THE IMPACT OF TECHNOLOGY- ASSISTED INSTRUCTION ON THEIR ENGLISH AURAL/ORAL SKILLS}

\begin{abstract}
The present study aimed to investigate the perceptions of Iranian English as Foreign Language (EFL) learners regarding the impact of technology-assisted instruction through the utilization of Information and Communication Technologies (ICTs) on their listening comprehension and speaking ability. To this end, eighty Iranian EFL learners whose age range was between twenty to thirty five took part in the study. They were randomly divided into four groups and were exposed to technology-assisted instruction on their course-related contents through different ICTs as their out-ofclass activities for one hour per week during two and a half months. The ICTs which were the focus of this study included: Podcasts, YouTube, Skype, and Instagram. The analysis of the participants' answers indicated that the majority of them (83.8\%) were positive toward technology-assisted instruction. In addition, $80 \%$ of them tended to use ICTs for their future language learning purposes.
\end{abstract}

Keywords: ICTs; Instagram; Iranian EFL Learners; Listening Comprehension; Podcasts; Skype; Speaking Ability; Technology-Assisted Instruction; YouTube.

\section{INTRODUCTION}

The problem setting. Nowadays, the widespread use of technology has revolutionized everybody's life. The use of technology is on the rise and it is here to stay. As a result, day by day we witness more and more of technology use in all aspects of our lives, and English Language Teaching (ELT) is not an exception.

Considering various sorts of instruction used in the history of teaching and learning, many fluctuations can easily be noticed. Some instructors are still in doubt about the usefulness of their instructional methods. In the era of Information Technology (IT), it is not surprising to see instructors who are taking advantage of new technologies like the Internet, ICT tools, etc. to enhance both the quality of their own instruction and their students' active role in learning. On the basis of these new teaching methods, the role of teachers has changed from an authoritative into a facilitative one, and that of students from a passive user of materials into an active processer of them. In addition, through using technology, greater individualization, social interaction, and reflection on language might be possible.

According to Young (2012), the major disadvantage of traditional face-to-face instruction is that it is bound to a certain time and space. This limitation might lead to students' losing the chance of interacting with both teachers and peers as soon as they leave the class which cannot be ignored at the age of communication technologies.

To overcome this shortcoming of traditional face-to-face instruction, 'e-learning' came into vogue. This method of instruction gave learners the chance of learning at any time or any place. On the contrary, there existed a lot of teachers and educators who were strongly in favor of the 
role a teacher can play in a language class. As a result, 'blended learning' came into existence which is an amalgamation of the best attributes of both traditional face-to-face instruction and online learning. 'Technology-assisted instruction' can be considered as an instance of 'blended learning'. Being broad in scope, technology-assisted instruction does not have a very accurate definition that all scholars agree on. But generally, it can be defined as any form of instruction where technologies are used and applied to facilitate, assist, and enhance the quality of teaching and learning. According to JISC (2009), technology-assisted instruction can be conceived as a continuum, beginning with the traditional classroom-based/face-to-face instruction, supported by technology, moving to a more flexible, blended approach which greatly utilizes technology and makes less use of face-to-face contact, and ending in an entirely online approach which thoroughly relies on technology. Due to the fact that 'Technology-assisted instruction' is an almost recent concept, little is known about the perceptions of teachers and especially learners regarding its effectiveness in language learning compared with the traditional face-to-face instruction.

Another issue which will be addressed in this study is related to ICT tools which are highly accessible and popular nowadays. Blurton (1999) regards ICTs as different pieces of technological devices and resources which are employed to communicate, produce, broadcast, and cope with information. ICTs have played vital roles in facilitating teaching and learning. They have altered classroom communication methods and modified instruction strategies. Since ICTs are intuitively robust and interactive, they have the capacity of satisfying each student's demands by providing situations to direct his/her learning; to search for information and accomplish activities in such a way that his/her needs and interests are totally met (Computer based technologies in English KLA, 1997). As such, this study seeks to first expose learners to different ICT tools like Podcasts, YouTube, Skype, and Instagram and then find out what their perceptions are of the use of such tools to enhance their listening comprehension and speaking ability.

Analysis of recent studies and publications. In 1993, a team of talented scholars headed by Dr. C. Ray Graham, from Brigham Young University, combined their knowledge to devise a methodology of teaching which blends the best of technologies with the most influential teaching practices and as a result technology-assisted instruction came into existence. Their purpose behind proposing such a method of instruction was to teach students in a way that they not only comprehend information, but also keep it in their minds and put it into use in their lives.

A significant amount of scientific works in the literature is devoted to the teachers' and students' opinions, attitudes or perceptions regarding both technology-assisted instruction and the ICTs which are the focus of this study.

Chiu (2003) investigated the attitudes of 300 college students towards Computer-Assisted Language Learning (CALL) in Taiwan. The findings indicated that the participants hold a positive stance toward using computers as they were learning English. Besides, male participants were more in favor of CALL than female ones.

Monk, Ozawa and Thomas (2006) in a study conducted at a Japanese university concluded that learners did not have positive attitudes and perceptions toward podcasting as an educational material. The researchers suggested overabundance of untargeted materials and lack of design perspective as the probable reasons behind learners' lack of interest in using podcasts.

Albirini (2006) explored the attitudes of high school EFL teachers about ICTs in Syria. The findings revealed that teachers had positive attitudes toward ICTs in education. Eugene (2006) examined the way teachers' attitudes and beliefs might influence the integration of technology in their classes. A questionnaire was used as the instrument to evaluate the attitudes and beliefs of 
32 teachers in this regard. Moreover, in order to discover the correlation between the teachers' attitudes and the implementation of technology in their teaching practices, a classroom observation technique was utilized. The result indicated that there was a mismatch between the teachers' beliefs and their actual integration of technology in their lessons.

Kavaliauskienè and Anusiene (2009) conducted a survey to investigate the perceptions of learners regarding listening to online podcasts. Most of the participants (76\%) had positive attitudes toward the techniques of enhancing their listening skills through using podcasts.

In 2009 a study was carried out by Park and Son to investigate the factors which might have an impact on EFL teachers' use of computers in their classrooms, their perceptions regarding CALL, and the ways to enhance CALL practice in school settings. Twelve Korean EFL teachers participated in this study. A questionnaire and follow-up in-depth interviews were employed to collect data. The findings indicated that the teachers were mostly in favor of the use of the computers. They believed that computer technology can enhance the quality of instruction by proposing different types of language input, and increasing students' learning experiences in real life context. Moreover, shortage of time, strict school curricula and text books, inadequate computer facilities, and the absence of administrative support were mentioned as the external factors which negatively affected the utilization of CALL in classrooms. In addition, internal factors like restricted computer skills of teachers, their knowledge about computers and their perceptions of CALL could greatly influence teachers' decisions on the implementation of CALL.

Li (2010) investigated the perceptions of secondary six English as a Second Language (ESL) students in Hong Kong regarding the use of podcasting in English learning. All of the participants believed that podcasts had improved their language skills.

Stiffler, Stoten and Cullen's study in 2011 indicated that learners mostly did not have positive attitudes toward podcasting. They believed that written materials could be understood much better than podcasting. Kim and King (2011) maintained that teachers and students' attitudes toward podcasts differed in accordance with their prior experiences with different kinds of computer technologies. Their case study was conducted on three English for Speakers of Other Languages (ESOL) teacher candidates and investigated their perceptions of and their attitudes toward the use of podcasts and blogs in a core assignment. The data were collected through observations, interviews, dialogues, research field notes, emails and a pre-term anonymous survey. Kim and King's study indicated the ways teachers integrated podcast and blog while developing a case study for a particular English language learner in an authentic classroom context.

Hismanoglu (2012) studied the perceptions of prospective EFL teachers in the distance higher education system toward the integration of ICT in EFL teaching. Most of the participants who had negative attitudes toward ICT implementation believed that the nature, level and delivery of their training were insufficient and as a result they affirmed that they did not feel to have a good command of ICTs in a way that they could use them in their future subject teaching. The results of the study indicated that it was essential to train teachers to become competent in and receptive to ICTs in distance education realms.

Yunus and Suliman (2014) presented a study conducted in Asia, which showed $89.6 \%$ of the students involved in the study agreed that using ICT had improved their overall language skills.

Shah, and Empungan (2015) carried out a study to investigate the attitudes of Malaysian ESLteachers towards the implementation of ICTs in literature lessons. The study indicated that 
teachers used ICTs on the satisfactory level. Besides, they hold an acceptable positive attitude towards the integration of ICT tools in Literature lessons.

Ogden (2015) carried out a study to find out the perceptions of students and teachers about the usefulness of Skype in online remedial English composition courses by means of interacting with the teacher. The results indicated that both teachers and students found interactions through Skype to be effective in improving students' writing due to being easy to use, creating a friendly environment, indispensableness, and skill acquisition.

Salbego, and Tumolo (2015) investigated teachers and students' perceptions regarding synchronous Skype classes. Participants answered a questionnaire about their experiences with online classes, in relation to face-to face learning environments. In general, participants thought of web conferencing as potential for language learning, with emphasis on the speaking and listening skills.

The article's goal. Taking the previous studies into account, one can easily notice the absence of a study conducted on the perceptions of Iranian EFL learners about technologyassisted instruction by using various ICTs like Podcasts, YouTube, Skype, and Instagram in order to improve their listening comprehension and speaking ability. Therefore, the aim of this article is to expose students to technology-assisted instruction through using different ICTs like Podcasts, YouTube, Skype, and Instagram in order to discover their perceptions of the impact of ICTs' on their listening comprehension and speaking ability.

\section{METHODS}

In this part, the participants of the study, the instrument used in the study, and the procedure followed in the study are presented. Finally, a brief explanation of the data collection and analysis is provided.

Participants. The participants of this study were eighty Iranian EFL students at the Kish Language Institute, Shiraz Branch, Iran, who were exposed to technology-assisted instruction through ICTs like Podcasts, YouTube, Skype, and Instagram for two and a half months. Their age range was between twenty to thirty five. Of this number, twenty four were males and fifty six were females.

Instrument. The instrument used in this study was a questionnaire which was adapted from Behjat, Yamini, and Bagheri's study in 2012 and entailed twenty eight open-ended questions that the participants were supposed to answer at the end of their instruction in thirty minutes (Appendix).

Procedure. First, the participants of this study were divided into four groups randomly. All the participants took their routine lessons in the form of traditional face-to-face instruction. However, their out-of-class activities were different. Each group was exposed to different ICT tools as their out-of-class activities for one hour per week during two and a half months. To meet this end, the participants of the first group were asked to download and listen to the teacherrecommended Podcasts whose topics were in accordance with their weekly course contents. The participants of the second group were asked to download and watch the teacher recommended videos on YouTube whose contents were related to their weekly lessons. The participants of the third group were given a timetable to interact with the teacher on Skype on the topics related to their weekly lessons. The schedule had flexibility so that if a participant could not afford interacting with the teacher at the specified time, a substitute participant would compensate for that. Therefore, no time was wasted this way. The participants of the fourth group were exposed 
to Instagram which included the video files related to their weekly course contents that were shared by the teacher. This fact is worth considering that in all groups, firstly all ICT tools were introduced to the participants and then the ways they could be used were explained to them thoroughly. So, all of the participants were technology-wise. Moreover, to make sure that the participants had listened to or watched the assigned audio or video files, they were asked to make a report of what had been watched or listened to and either present it orally to the class or hand over their written summaries to the teacher at the beginning of every session. After the instruction which lasted for two and a half months, the data were gathered through a questionnaire which is presented in the appendix.

Data collection and data analysis. The data which were gathered through the questionnaire (See Appendix) were classified into three groups: 'Agree', 'Disagree', and 'Undecided'. 'Agree' indicated that the participants were in favor of using ICT tools, 'Disagree' showed that the participants were against using ICT tools, and 'Undecided' revealed that they had no idea of using ICT tools for their future language learning purposes. The participants' comments were then analyzed by running a Chi-square and after that were shown in the form of frequencies, and percentages.

\section{FINDINGS}

As mentioned before, the data were gathered through a questionnaire which aimed at finding answers to these five broad categories:

1. Identify the students' ideas on the usefulness of the ICT tools and their tendencies to employ them for language learning purposes.

2. Determine the positive effects of ICT tools on learners' language studies.

3. Discover if the participants would rather have technology-assisted instruction.

4. Determine if the participants felt reassured and experienced enough to employ the ICT tools for their future language learning by themselves.

5. Find out if they would utilize ICT tools like Podcasts, Skype, YouTube, and Instagram to enhance their listening comprehension and speaking ability.

The participants' answers to these questions were coded. Each answer was marked with an identification number. Next, the coding was done through converting the answers to the questions into three categories: 'Agree', 'Disagree', 'Undecided'. Considering the tendency to utilize ICT tools for language learning purposes, the following responses were obtained.

\section{Coded as "Agree":}

"This course gave me motivation to learn English independent of the teacher from now on." "I am now more eager to learn English than before."

"Now, I am more familiar with ICT tools which are at my disposal for language learning purposes."

"ICT tools provided more opportunities for me to learn English."

"I like to share my experiences about the use of ICT tools for language learning purposes with my friends... I think they are the best way to learn English."

\section{Coded as "Disagree":}

"I like to attend traditional classes more."

"These classes with a lot of assigned out-of-class activities are very boring to me."

"Out-of-class activities are very time-consuming."

\section{Coded as "Undecided":}

"I am not sure." 
On the basis of the participants' comments, the frequency of their positive, negative, and uncertain answers to the first question was recorded and then a Chi-square was run to calculate the related percentages. Its results are indicated in Table 1.

Table 1.

Tendency to Employ ICT Tools

\begin{tabular}{|c|c|c|c|}
\hline Question codes & Male & Female & Total \\
\hline \multirow{2}{*}{ Agree } & 18 & 46 & 64 \\
& $75 \%$ & 82.1 & $80 \%$ \\
\hline \multirow{2}{*}{ Disagree } & 3 & 7 & 10 \\
& $12.5 \%$ & $12.5 \%$ & $12.5 \%$ \\
\hline \multirow{2}{*}{ Undecided } & 3 & 3 & 6 \\
& $12.5 \%$ & $5.4 \%$ & $7.5 \%$ \\
\hline \multirow{2}{*}{ Total } & 24 & 56 & 80 \\
& & & $100 \%$ \\
\hline
\end{tabular}

As Table 1 reveals, whereas $80 \%$ of the participants preferred to employ ICT tools, only $12.5 \%$ disagreed with their use. Moreover, just $7.5 \%$ of the participants were unsure about having the tendency to use ICT tools in general. On the contrary, from all male participants, $75 \%$ gave a positive answer, $12.5 \%$ a negative answer, and $12.5 \%$ an uncertain answer to the first question. Similarly, out of 56 female participants, $82.1 \%$ gave a positive answer, $12.5 \%$ a negative answer, and $5.4 \%$ an uncertain answer to the first question.

Considering the impact of the ICT tools on language studies, some of the participants' answers are as follows:

\section{Coded as "Agree":}

"They have assisted me to be a better listener."

"This course has advanced my conversational skills."

"My listening and speaking have improved a lot ever since I attended this course."

\section{Coded as "Disagree":}

"My speaking and listening are as poor as before."

"It could not solve the problems I had while communicating with others."

\section{Coded as "Undecided":}

"It depends."

"My scores haven't changed for better at all."

When the number of agree, disagree, and undecided was counted, then a Chi-square was run to calculate the related percentages. See Table 2 for its results.

Table 2.

\section{ICT Tools' Impact on Language Study}

\begin{tabular}{|c|c|c|c|}
\hline Question codes & Male & Female & Total \\
\hline \multirow{2}{*}{ Agree } & 18 & 48 & 66 \\
& $75 \%$ & $85.7 \%$ & $82.5 \%$ \\
\hline \multirow{2}{*}{ Disagree } & 3 & 3 & 6 \\
& $12.5 \%$ & $5.4 \%$ & $7.5 \%$ \\
\hline \multirow{2}{*}{ Undecided } & 3 & 5 & 8 \\
& $12.5 \%$ & $8.9 \%$ & $10 \%$ \\
\hline \multirow{2}{*}{ Total } & 24 & 56 & 80 \\
& & & $100 \%$ \\
\hline
\end{tabular}


On the basis of Table 2, about $82.5 \%$ of participants believed that ICT tools could help them promote their language studies. $7.5 \%$ believed that ICT tools did not have any positive impacts on their language studies. And only $10 \%$ of all participants were uncertain about the positive influence of ICT tools on their language studies. Considering females' answers, 85.7\% answered positively, $5.4 \%$ negatively, and $8.9 \%$ were uncertain about the second question. $75 \%$ of male participants answered positively, $12.5 \%$ of them answered negatively and $12.5 \%$ were uncertain about the second question.

Regarding the third question which has to do with the participants' preference to have technology-assisted instruction, the following responses have been provided by the participants:

\section{Coded as "Agree":}

"Working with my teacher out of the class was a new experience for me."

"My English has improved a lot. I prefer to attend other online classes from now on."

"Using ICT tools for language study was really fun and motivating."

\section{Coded as "Disagree":}

"I have a lot of problems with filtering. As a result, I prefer traditional face-to-face instruction."

"My Internet disconnects in the middle of conversing with others. This fact makes me too nervous."

"The Internet rate in Iran is very low, and it is a big hindrance to download films and audios."

"ADSL connection in Iran costs a lot."

\section{Coded as "Undecided":}

"It depends, maybe it can help those who have access to broadband Internet connection." "Perhaps in some large cities with a lot of facilities."

Having counted the number of agree, disagree, and undecided responses, the researcher ran a Chi-square to calculate the related percentages. The results are illustrated in Table 3.

\section{Having Technology-assisted Instruction}

Table 3.

\begin{tabular}{|c|c|c|c|}
\hline Question codes & Male & Female & Total \\
\hline \multirow{2}{*}{ Agree } & 20 & 47 & 67 \\
& $83.3 \%$ & $83.9 \%$ & $83.8 \%$ \\
\hline \multirow{2}{*}{ Disagree } & 1 & 6 & 7 \\
& $4.2 \%$ & $10.7 \%$ & $8.8 \%$ \\
\hline \multirow{2}{*}{ Undecided } & 3 & 3 & 6 \\
& $12.5 \%$ & $5.4 \%$ & $7.5 \%$ \\
\hline \multirow{2}{*}{ Total } & 24 & 56 & 80 \\
& & & $100 \%$ \\
\hline
\end{tabular}

As Table 3 indicates, $7.5 \%$ of the participants were undecided about having technologyassisted instruction. Although, $83.8 \%$ agreed to have it, $8.8 \%$ did not want to have technologyassisted instruction at all. Of all males, $83.3 \%$ gave a positive answer, $4.2 \%$ a negative answer, and $12.5 \%$ an uncertain answer to the third question. Whereas, $83.9 \%$ of females agreed, $10.7 \%$ disagreed, and $5.4 \%$ were undecided regarding the third question. 
Considering the fourth question, the participants were asked if they felt reassured and experienced enough to employ the ICT tools for their future language learning by themselves. Participants answered in the following way:

Coded as "Agree":

"It was sufficient to teach me how to use ICT tools on my own for my language learning."

"It taught me how to use the Internet and ICT tools to learn a language, make new friends, and have fun."

"I recognized that I can learn English even without attending classes."

\section{Coded as "Disagree":}

"I have a dependent personality type. And learning a language is not an exception. Thus, I am too dependent on my language teachers as well."

"The term was not long enough to enable me to learn how to use ICT tools on my own."

\section{Coded as "Undecided":}

"I am not certain about using them for my future language studies."

"Maybe I try in future."

Table 4 represents the participants' answers to the fourth question in both frequencies and percentages, after running a Chi-square on their answers.

\section{Using the ICT Tools for Future Language Learning}

Table 4.

\begin{tabular}{|c|c|c|c|}
\hline Question codes & Male & Female & Total \\
\hline \multirow{2}{*}{ Agree } & 18 & 45 & 63 \\
& $75 \%$ & $80.4 \%$ & $78.8 \%$ \\
\hline \multirow{2}{*}{ Disagree } & 2 & 7 & 9 \\
& $8.3 \%$ & $12.5 \%$ & $11.2 \%$ \\
\hline \multirow{2}{*}{ Undecided } & 4 & 4 & 8 \\
& $16.7 \%$ & $7.1 \%$ & $10 \%$ \\
\hline \multirow{2}{*}{ Total } & 24 & 56 & 80 \\
& & & $100 \%$ \\
\hline
\end{tabular}

According to Table $4,78.8 \%$ of students participating in the study and working with ICT tools, gained enough confidence and experience to use the ICT tools for their future language learning. $11.2 \%$ disagreed to use the ICT tools for their future language learning, and $10 \%$ were undecided in this regard. Of all women, $80.4 \%$ agreed, $12.5 \%$ disagreed, and $7.1 \%$ were undecided. Considering the male participants, $75 \%$ answered positively, $8.3 \%$ answered negatively, and $16.7 \%$ were undecided in this regard.

The last question of the questionnaire had to do with the participants' opinions toward the program. The researcher was into knowing what their overall idea was about using Podcast, YouTube, Skype, and Instagram. Consequently, this question was raised, "would you like to use ICT tools (podcast, YouTube, Skype, and Instagram) to enhance your listening comprehension and speaking ability in your future language learning?" In what follows, you see some of the students' comments regarding the question:

\section{Coded as "Agree":}

"Speaking online with our teacher through Skype helped me a lot to recognize where my shortcomings were in speaking, especially pronunciation, and stress." 
"Downloading the related films from the YouTube was an exciting experience and helped me to have a clear picture of the contexts in which some grammatical points were used in practice."

"Listening to podcasts in my free time and on my way to school was like a miracle which assisted me to improve my listening a lot."

"Personally I am into Instagram. And when the teacher explained to me the way I could download the audios and films related to my lessons, it was like a key to success. Since I could learn a language, and connect with my friends at the same time."

\section{Coded as "Disagree":}

"Because I do not have access to Wi-Fi, I prefer to attend traditional language classes."

"Filtering caused a lot of problems for downloading films from the YouTube, and this made me really nervous."

"The Internet is too expensive, and downloading some audios and films cost me a lot."

\section{Coded as "Undecided":}

"It depends. In some situations, maybe they can be useful."

"I am not sure yet." Table 5

Having run a Chi-square on the participants' answers, the obtained result is presented in

ICT Tools in the Improvement of Listening and Speaking Ability

Table 5.

\begin{tabular}{|c|c|c|c|}
\hline Question codes & Male & Female & Total \\
\hline \multirow{2}{*}{ Agree } & 23 & 48 & 71 \\
& $95.8 \%$ & $85.7 \%$ & $88.8 \%$ \\
\hline \multirow{2}{*}{ Disagree } & 1 & 5 & 6 \\
& $4.2 \%$ & $8.9 \%$ & $7.5 \%$ \\
\hline \multirow{2}{*}{ Undecided } & 0 & 3 & 3 \\
& $0 \%$ & $5.4 \%$ & $3.8 \%$ \\
\hline \multirow{2}{*}{ Total } & 24 & 56 & 80 \\
& & & $100 \%$ \\
\hline
\end{tabular}

As the Table 5 indicates, $88.8 \%$ of participants liked to use ICT tools (podcast, YouTube, Skype, and Instagram) to improve their listening comprehension and speaking ability for their future language learning. 7.5\% disagreed with the first group, and only 3.8\% were undecided in this regard. Considering the male participants, $95.8 \%$ gave a positive answer, $4.2 \%$ a negative answer, and $0 \%$ an uncertain answer to the fifth question. Of all women, $85.7 \%$ agreed, $8.9 \%$ disagreed, and 5.4\% were undecided about using ICT tools to improve their listening comprehension and speaking ability for their future language learning.

\section{THE CONCLUSIONS AND PROSPECTS OF FURTHER RESEARCH}

The analysis of the students' replies to the relevant questions showed that the majority of the students had a positive attitude toward using ICT tools for their language learning purposes. Most of the students were content with the program and really admired the use of ICT tools for their language learning. The following portrays their comments: 
"Working with my teacher out of the class was a new experience for me."

"My English has improved a lot. I prefer to attend other online classes from now on."

"Using ICT tools for language study was really fun and motivating."

"It was sufficient to teach me how to use ICT tools on my own for my language

learning."

"It taught me how to use the Internet and ICT tools to learn a language, make new

friends, and have fun."

"I recognized that I can learn English even without attending classes."

It is worth mentioning that there were only a few students who disagreed with the program. Because they might have connection, or filtering problems. In sum, the students' encouraging remarks made the researcher conclude that they were both experienced and confident enough to utilize the ICT tools for their future language studies. The findings of this study are in line with a number of previously conducted pieces of research. For instance, Chiu's study (2003) which revealed that the participants had a positive attitude toward learning English by using computers. Besides, Lord's study (2008) that assessed students' attitudes toward podcasts and found that they had a positive attitude toward its use during their semester is in agreement with the present study. Anusiene 's survey in 2009 which indicated positive attitudes to the techniques of developing listening skills by using podcasts is also in line with the present research. Furthermore, Li's study in 2010 which explored that all of the participants agreed Podcasts had enhanced their language skills, the survey by Canning-Wilson (2000) which suggested that the students like learning language through the use of videos, Salbego, and Tumolo's research in 2015 which concluded that web conferencing was perceived as potential for language learning, with emphasis on the speaking and listening skills, can all be in agreement with the obtained result of this study. However, the findings of the present study might be in contrast with a study done by Monk, Ozawa and Thomas (2006) at a Japanese university which revealed that learners did not have positive attitudes and perceptions of podcasting as an ICT tool to improve their language learning.

In addition, the researcher came up with some topics for those who are into work in the same line of research:

1. The participants of this study were all elementary English students. The same research might be done with students at other levels of language proficiency.

2. As the major focus of the present study was on listening and speaking skills, similar studies can be done on other language skills and subskills.

3. The Iranian EFL learners' perceptions of the impacts of only four ICT tools were examined in the present study. Their perceptions regarding the effectiveness of other ICT tools like Vodcasts, Telegram, What'sApp, etc. can also be studied.

4. To gain a broader insight, observations, diaries, semi-structured interviews, or 'a focused group interview' might be used.

5. The amount of exposure to ICTs can be changed to discover whether learners have the same attitude toward technology-assisted instruction or not.

In conclusion, teachers, material developers, and syllabus designers can take advantage of this positive perception to integrate technology into teaching/learning activities to make this process more enjoyable and less limited to classroom boundaries. 


\section{ACKNOWLEDGEMENT}

This piece of research would have not been accomplished without the support, guidance, and contribution of so many individuals. I am greatly indebted to all the participants who generously gave me their invaluable time by kindly taking part in this project. I would also like to express my special appreciation and thanks to the executive editor of this journal, Irina Malitskaya, for all her contributions of time, and ideas to make my article more fruitful. Moreover, I am really thankful to all the reviewers who kindly informed me of their insightful remarks regarding this article. Finally, a million thanks to my mother. Words cannot express how grateful I am to her for all of the sacrifices that she made on my behalf. Her prayer for me was what sustained me thus far.

\section{REFERENCES}

1. Albirini, A. 2006. Teachers' attitudes toward information and communication technologies: The case of Syrian EFL teachers, Computers \& Education 47, 373-398.

2. Canning-Wilson, Ch. 2000. Practical aspects of using video in the foreign language classroom, The Internet TESL Journal, VI (11). Available from: http://iteslj.org/Articles/Canning-Video.html

3. Chiu, M. W. 2003. Computer-assisted language learning: Attitudes of Taiwanese college students, Unpublished $\mathrm{PhD}$ dissertation, University of West Florida.

4. Computer-based technologies in the creative arts KLA: Enhancing student learning. 1997. Available from http://trove.nla.gov.au/version/8701994

5. Eugene, J. 2006. How teachers integrate technology and their beliefs about learning: Is there a connection? Journal of Technology and Teacher Education, 14(3), 581-597.

6. Hismanoglu, M. 2012. Prospective EFL teachers' perceptions of ICT integration: A study of distance higher education in Turkey. Educational Technology \& Society, 15 (1), 185-196.

7. JISC. 2009. Effective Practice in a Digital Age: A guide to technology-enhanced learning and teaching. Available from: https://www.dkit.ie/system/files/Effective\%20practice\%20in\%20a\%20digital\%20age\%20JISC_0.pdf

8. Kavaliauskienè, G., \& Anusienè, L. 2009. English for specific purposes: Podcasts for listening skills, Santalka. Filologija. Edukologija, 17(2), 28-37.

9. Kim, D., \& King, K. 2011. Implementing podcasts with ESOL teacher candidates' preparation: Interpretations and implication. International Forum of Teaching and Studies, 7(2), 5-19.

10. Li, H. C. 2010. Using podcasts for learning English: Perceptions of Hong Kong secondary 6 ESL students. ELT World Online, 4, 78-90.

11. Monk, B., Ozawa, K., \& Thomas, M. 2006. iPods in English language education: A case study of English listening and reading students. NUCB journal of language culture and communication, 8(3), 85-102.

12. Ogden, D. 2015. Skype as a scaffolding tool for underprepared freshmen English composition students, Unpublished $\mathrm{PhD}$ dissertation, Walden University.

13. Park, Ch. N., \& Son, J-B. 2009. Implementing computer-assisted language learning in the EFL classroom: teachers' perceptions and perspectives. International Journal of Pedagogies and Learning, 5 (2). 80-101.

14. Salbego, N. N., \& Tumolo, C. H. S. 2015. Skype Classes: Teachers and students' perceptions on synchronous online classes in relation to face-to-face teaching and learning, International Journal of Language and Applied Linguistics, 1 (3), 36-45.

15. Shah, P. M., \& Empungan, J. L. 2015. ESL teachers' attitudes towards using ICT in literature lessons, International Journal of English Language Education, 3 (1), 201-218.

16. Stiffler, D., Stoten, S., \& Cullen, D. 2011. Podcasting as an instructional supplement to online learning. Computers, Informatics, Nursing, 29(3), 144-148.

17. Young, M. 2012. Exploring the pros and cons of online, hybrid, and face-to-face class formats, leading change in public higher education: A provost report series on trends and issues facing higher education. Available from: http://www.washington.edu/provost/files/2012/11/edtrends_Pros-Cons ClassFormats.pdf

18. Yunus, M. M., \& Suliman, A. 2014. Information and Communication Technology (ICT) tools in teaching and learning literature component in Malaysian secondary schools, Asian Social Science, 10 (7), 136-152.

Text of the article was accepted by Editorial Team 11.12.2016. 


\section{APPENDIX}

1. How often do you use your computer? For what purposes do you usually use it?

2. Do you have your own PC or laptop with Internet access?

3. What basically made you buy an Internet account?

4. How many hours a day do you use the Internet?

5. In what languages do you communicate on the Internet?

6. What do you usually use the Internet for? (Chat; e-mail; news; social media; shopping: etc.)

7. How many sites do you visit per session?

8. What are your favorite places on the Net?

9. What has been your greatest triumph using the Internet?

10. What has been your greatest barrier in using the Internet?

11. Which Internet feature have you found the most valuable? Why?

12. How did you acquire your knowledge in using computer technology and the Internet?

13. Would you like to take part in technology-assisted or distance learning courses from now on?

14. Have the Internet and technology had an impact on your professional development and studies? How?

15. Do you find the World Wide Web and Social Media beneficial in your studies?

16. Do you think using the Internet is a significant aspect of being a student? Why?

17. Do you think using ICT tools in education improves your language learning process?

18. Do you prefer to have technology-assisted or on-line instruction or assignment?

19. Do you enjoy using podcasts, YouTube, Skype, or Instagram? Why?

20. Before participating in this project, were you familiar with ICT tools like Podcasts, YouTube, Skype, or Instagram?

21. What was the main problem in using ICT tools like podcasts, YouTube, Skype, or Instagram?

22. Do you prefer technology-assisted instruction to traditional face-to-face instruction for learning the listening comprehension or speaking?

23. Did you get enough experience to use ICT tools for your language learning later on?

24. Is it good if your English teachers use ICT tools like Podcasts, YouTube, Skype, or Instagram for educational purposes?

25. Do you think using podcasts, YouTube, Skype, or Instagram in education are interesting?

26. What is your overall opinion about podcasts, YouTube, Skype, or Instagram?

27. Generally, are you satisfied with using podcasts, YouTube, Skype, or Instagram for listening comprehension and speaking skill in a foreign language?

28. What are your general comments on this program?

\section{СПРИЙНЯТТЯ ІРАНСЬКИМИ СТУДЕНТАМИ НАВЧАННЯ 3 ТЕХНОЛОГІЧНОЮ ПЦДТРИМКОЮ СПРЯМОВАНОГО НА РОЗВИТОК ЇХ СЛУХОВИХ ТА УСНИХ НАВИЧОК}

\section{Розі Сузанзан}

викладач англійської мови, аспірант з TEFL

кафедра англійської мови, філія Шираз, Ісламський університет Азад, Шираз, Іран

r.souzanzan@yahoo.com

\section{Мохаммад Садег Багері}

доцент, PhD 3 TEFL

кафедра англійської мови, філія Шираз, Ісламський університет Азад, Шираз, Іран

bagheries@gmail.com 


\begin{abstract}
Анотація. Дослідження спрямоване на проведення аналізу із сприйняття іранськими студентами, які вивчають англійську мову як іноземну (EFL - English as a Foreign Language), навчання 3 технологічною підтримкою, використовуючи інформаційно-комунікаційні технології (ІКТ), спрямованого на розвиток їх слухового сприймання і здатність говорити. 3 цією метою у дослідженні взяли участь вісімдесят іранських студентів EFL віком від двадцяти до тридцяти п'яти років. Вони були випадковим чином розділені на чотири групи, які проходили навчання 3 підтримкою технологій відповідно до їх учбових програм, використовуючи різні ІКТ під час їх позакласної діяльності протягом однієї години на тиждень, терміном двох 3 половиною місяців. ІКТ, які були використані в даному дослідженні, включали: подкасти, YouTube, Skype та Instagram. Аналіз відповідей учасників дослідження показав, що більшість 3 них $(83,8 \%)$ позитивно оцінили технологічно насичений процес навчання. Крім того, $80 \%$ студентів і надалі використовують ІКТ для вивчення мови.
\end{abstract}

Ключові слова: IKT; Instagram; іранські студенти EFL; аудіювання; подкасти; Skype; здатність говорити; викладання з технологічною підтримкою; YouTube.

\title{
ВОСПРИЯТИЕ ИРАНСКИХ СТУДЕНТОВ ТЕХНОЛОГИЧЕСКИ ПОДДЕРЖИВАЮЩЕГО ОБУЧЕНИЯ НАПРАВЛЕННОГО НА РАЗВИТИЕ ИХ СЛУХОВЫХ И УСТНЫХ НАВЫКОВ
}

\section{Рози Сузанзан}

преподаватель английского языка, аспирант TEFL

кафедра английского языка, филиал Шираз, Исламский университет Азад, Шираз, Иран

r.souzanzan@yahoo.com

Мохаммад Садег Багери

доцент, PhD в TEFL

кафедра английского языка, филиал Шираз, Исламский университет Азад, Шираз, Иран

bagheries@gmail.com

\begin{abstract}
Аннотация. Настоящее исследование направлено на изучение восприятия иранскими студентами, изучающих английский язык как иностранный (EFL - English as a Foreign Language), обучения c технологической поддержкой, используя информационнокоммуникационные технологии (ИКТ), направленного на развитие их слухового восприятия и способность говорить. С этой целью, в исследовании приняли участие восемьдесят иранских учащихся EFL возрастом от двадцати до тридцати пяти лет. Они были случайным образом разделены на четыре группы и проходили обучение с поддержкой технологий соответствующее их учебной программе, используя различные ИКТ во время их внеклассной деятельности в течение одного часа в неделю, на протяжении двух с половиной месяцев. ИКТ, которые были использованы в данном исследовании, включали: подкасты, YouTube, Skype и Instagram. Анализ ответов участников исследования показал, что большинство из них $(83,8 \%)$ положительно оценили технологически насыщенный процесс обучения. Кроме того, $80 \%$ студентов и в дальнейшем используют ИКТ для изучения языка.
\end{abstract}

Ключевые слова: ИКТ; Instagram; иранские студенты EFL; аудирование; подкасты; Skype; способность говорить; преподавание с технологической поддержкой; YouTube.

Conflict of interest. The authors have declared no conflict of interest.

\section{(cc) BY-NC-SA}

This work is licensed under Creative Commons Attribution-NonCommercial-ShareAlike 4.0 International License. 